\title{
TUMBUH KEMBANG ANAK USIA 0-5 TAHUN
}

\author{
Merita \\ Program Studi Ilmu Gizi, STIKes Baiturrahim Jambi \\ email:merita_meri@yahoo.com
}

\begin{abstract}
Some of the effects of child development that are not in accordance with their age can inhibit brain development. Therefore, the purpose of this service is to carry out counseling on growth and development in children under five age. This activity was held from September 2018 to January 2019, at the Sukasari Posyandu, Sarolangun District. Sasaran is a mother who has children aged 0-5 years. This activity consisted of giving counseling with power point media, leaflets, posters, and pre-post test questions and anthropometric measurements of toddlers. The output of this service activity are: (1) Media leaflets and posters of child development and; (2) Mother's behavior in monitoring child growth and development. The results of the activity showed that participants were able to answer questions related to growth material in children aged $0-5$ years in the post-test stage, ie correct answers of $\geq 80 \%$. Participants are also able to understand the material about child development related to good consumption patterns through discussion. Based on this activity, it is necessary to collaborate with health workers and cadres to motivate children under five to routinely monitor the growth of children under five to posyandu or the nearest health care facility.
\end{abstract}

Keywords: Toddlers; Posyandu; Growth and Development

\begin{abstract}
ABSTRAK
Beberapa dampak akibat dari tumbuh kembang anak yang tidak sesuai dengan usianya diantara lain dapat menghambat perkembangan otak. Oleh karena itu, tujuan pengabdian ini adalah untuk melakukan penyuluhan tumbuh kembang pada anak balita. Kegiatan ini dilaksanakan pada bulan September 2018 sampai Januari 2019, di Posyandu Sukasari Kabupaten Sarolangun. Sasaran adalah ibu yang mempunyai anak usia 0-5 tahun. Kegiatan ini terdiri dari pemberian penyuluhan dengan media power point, leaflet, poster, serta soal pre-post test dan pengukuran antropometri balita. Luaran dari kegiatan pengabdian ini yaitu: (1) Media leaflet dan poster tumbuh kembang anak dan; (2) Perilaku ibu dalam pemantauan tumbuh kembang anak. Hasil kegiatan menunjukkan bahwa peserta mampu menjawab pertanyaan terkait dengan materi tumbuh kembang pada anak usia 0-5 tahun pada tahap post-test, yaitu jawaban benar sebesar $\geq 80 \%$. Peserta juga mampu memahami materi tentang tumbuh kembang anak terkait dengan pola konsumsi yang baik melalui diskusi. Berdasarkan kegiatan ini maka perlu upaya kerja sama dari petugas kesehatan dan kader untuk memotivasi ibu balita agar rutin melakukan pemantauan tumbuh kembang balita ke posyandu atau fasilitas pelayanan kesehatan terdekat.
\end{abstract}

Kata kunci: Balita; Posyandu; Tumbuh Kembang

\section{PENDAHULUAN}

Masa bayi adalah masa keemasan sekaligus masa kritis perkembangan seseorang. Dikatakan masa kritis karena pada masa ini bayi sangat peka terhadap lingkungan dan dikatakan masa keemasan karena masa bayi berlangsung sangat singkat dan tidak dapat diulang kembali (Departemen Kesehatan, 2010). Usia perkembangan bayi terbagi 2 yaitu, neonatus sejak lahir sampai usia 28 hari dan bayi dari usia 29 hari sampai 12 bulan (WHO, 2013).

Bayi adalah anak usia 0 sampai 12 bulan. Setiap bayi mengalami tahap 
pertumbuhan dan perkembangan dalam masa hidupnya. Pertumbuhan dan perkembangan merupakan proses yang berkesinambungan, bersifat kontinyu dan pertumbuhan merupakan bagian dari proses perkembangan (Rusli, 2013). Pertumbuhan yang meliputi perubahan tinggi badan, berat badan, gigi, struktur tulang, dan karakteristik seksual. Pertumbuhan ini bersifat kuantitatif. Sedangkan perkembangan seperti perkembangan motorik, sensorik, kognitif dan psikososial bersifat kualitatif (Potter \& Perry, 2010).

Fenomena yang terjadi di masyarakat masih banyak ditemukan bayi ataupun anak yang kenaikan berat badannya belum optimal mencapai berat badan ideal sesuai usia anak. Berdasarkan data RISKESDAS (Riset Kesehatan Dasar) tahun 2013 menyatakan bahwa prevalensi balita mengalami gizi kurang dan gizi buruk secara nasional pada tahun 2013 adalah $19,6 \%$ yang terdiri dari $5,7 \%$ balita mengalami gizi buruk dan $13,9 \%$ gizi kurang dilihat dari indikator $\mathrm{BB} / \mathrm{U}$. Jika dibandingkan dengan dengan angka prevalensi nasional tahun 2010 yaitu 18,0\% dan tahun 2010 yaitu $17,9 \%$ yang terlihat meningkat. Perubahan terutama pada prevalensi gizi buruk yaitu $5,4 \%$ tahun 2007, 4,9\% tahun 2010 dan 5,3\% tahun 2013. Sedangkan prevalensi gizi kurang naik sebesar 0,9\% dari 2007 dan 2013.

Diantara 33 provinsi di Indonesia, 19 provinsi memiliki prevalensi gizi burukkurang diatas angka prevalensi nasional yaitu berkisar antara $21,2 \%$ sampai dengan $33,1 \%$. Laporan Dinas Kesehatan Provinsi Jambi berdasarkan hasil analisis terhadap Riskesdas tahun 2010 menyebutkan bahwa prevalensi gizi kurang-buruk menurut indikator $\mathrm{BB} / \mathrm{U}$ adalah $19,6 \%$. Provinsi Jambi menduduki peringkat ke-17 dari 33 Provinsi di Indonesia, dimana prevalensinya nasionalnya adalah $18,0 \%$. Prevalensi balita stunting (pendek dan sangat pendek) menurut indikator $\mathrm{TB}(\mathrm{PB}) / \mathrm{U}$ adalah $30,2 \%$ menduduki peringkat ke-24 dari 33 Provinsi di
Indonesia, dimana prevalensi nasionalnya adalah 35,6\%. Prevalensi balita kurus dan sangat kurus menurut indikator $\mathrm{BB} / \mathrm{TB}$ menduduki peringkat ke-1 dari 33 Provinsi, dimana prevalensi nasionalnya adalah $13,3 \%$.

Beberapa dampak akibat dari tumbuh kembang anak yang tidak sesuai dengan usianya diantara lain dapat menghambat perkembangan otak, sering sakit / sistem imun yang menurun, rasa cemas atau takut yang berlebiha, emosi tidak terkontrol, dan gangguan kognitif (Syarif et al, 2011). Dampak jangka panjang lainnya berupa rendahnya kemampuan nalar dan prestasi pendidikan serta rendahnya produktifitas kerja (Achadi, 2014).

Berdasarkan informasi yang diperoleh dari Dinas Kesehatan Kabupaten Sarolangun bahwa masih banyak ditemukan kasus balita atau anak gizi kurang dan stunting sehingga perlu diberikan perhatian lebih serta perawatan yang optimal. Balita gizi kurang dan stunting merupakan salah satu contoh balita yang tumbuh kembang tidak sesuai dengan usianya atau tidak optimal. Oleh karena itu, tujuan pengabdian ini yaitu memberikan penyuluhan tentang "Tumbuh Kembang Anak Usia 0-5 Tahun" agar masyarakat khususnya para ibu dapat mengetahui bagaimana tumbuh kembang anak yang baik dan optimal.

\section{TARGET DAN LUARAN}

1. Target

Kegiatan pengabdian ini memiliki target khusus yaitu:

a. Sasaran mengetahui apakah pertumbuhan dan perkembangan anak sesuai dengan usianya.

b. Sasaran bersedia mengikuti pemaparan materi yang disampaikan tim penyuluh.

c. Sasaran dapat mengimplementasikan makanan tambahan berbahan lokal kepada anak.

2. Luaran 
Luaran dari kegiatan pengabdian ini yaitu:

a. Media leaflet dan poster tumbuh kembang anak

b. Perilaku ibu dalam pemantauan tumbuh kembang anak

\section{METODE PELAKSANAAN}

1. Waktu dan Tempat

Kegiatan ini dilaksanakan selama 6 bulan pada bulan September 2018 hingga Januari 2019 di Posyandu Kelurahan Sukasari, Kabupaten Sarolangun.

2. Tujuan

Tujuan dari kegiatan ini yaitu:

a. Menciptakan leaflet dan modul yang efektif dalam menyampaikan pesan pemantauan tumbuh kembang anak.

b. Ibu-ibu balita dan kader posyandu dapat mentransformasikan prinsip prinsip pemantauan tumbuh kembang anak secara berkesinambungan.

\section{Sasaran}

Sasaran dalam kegiatan ini adalah ibu yang mempunyai bayi dan balita usia 0-5 tahun yang ada di Posyandu Kelurahan Sukasari. Total sasaran adalah 15 orang.

4. Kontribusi Peserta Pengabdian

Adapun kontribusi sasaran dalam pengabdian masyarakat ini adalah:

1) Menjadi peserta kegiatan pengabdian

2) Mengikuti pre dan post test

3) Menjadi fasilitator bagi ibu-ibu balita lainnya dalam pemantauan tumbuh kembang anak.

5. Pelaksanaan Kegiatan Pengabdian

Tahapan pelaksanaan kegiatan pengabdian kepada masyarakat ini adalah sebagai berikut:

\section{Kegiatan Awal}

a) Menyusun proposal kegiatan pengabdian kepada masyarakat. b) Mendesain poster dan leaflet pemantauan tumbuh kembang anak.

c) Menyiapkan materi presentasi pemantauan tumbuh kembang anak untuk disampaikan kepada sasaran

d) Menyiapkan lembar pre-test dan post test tentang pemantauan tumbuh kembang anak.

\section{Pelaksanaan Kegiatan}

a) Perkenalan antara tim pengabdian kepada masyarakat dengan sasaran

b) Penjelasan kegiatan yang akan dilakukan dalam melibatkan sasaran

c) Memberikan lembar pre-test

d) Melaksanakan penyampaian pesan tumbuh kembang anak melalui media poster, leafleat dan video presentasi.

e) Mengadakan role playing dalam tumbuh kembang anak.

f) Memberikan lembar post-test

g) Penutupan

6. Monitoring dan Evaluasi

Monitoring dan evaluasi (Monev) dilakukan dengan teknik wawancara dan obeservasi langsung kepada sasaran. Cakupan Monev meliputi aspek perencanaan, pelaksanaan kegiatan, hasil kegiatan, dan dampak kegiatan.

\section{HASIL DAN PEMBAHASAN}

Posyandu Kelurahan Sukasari merupakan salah satu Posyandu yang terdapat di wilayah kerja Puskesmas Sarolangun. Posyandu ini terletak di pinggir jalan sehingga cukup strategis untuk menunjang kelancaran kegiatan Penyuluhan tentang "Tumbuh Kembang Anak Usia 0-5 Tahun" yang telah dilakukan sebelumnya. Posyandu tersebut dapat ditemukan dengan mudah dan tempatnya juga nyaman serta mendapatkan udara dan sinar matahari yang cukup karena berada diteras rumah warga. Secara umum Posyandu tersebut telah memenuhi persyaratan. Pada pelaksanaannya semua siswa/i menghadiri kegiatan sampai selesai sehingga capaian 
sasaran dalam kegiatan ini $100 \%$. Kegiatan ini didampingi oleh bidan desa dan kader posyandu sehingga diharapkan dapat mentransformasikan prinsip pemantauan tumbuh kembang anak secara berkesinambungan.

Sebelum dilakukan kegiatan penyuluhan perserta diberikan soal pre-test untuk mengukur pengetahuan awal sebelum diberikan penyuluhan. Pemberian materi disampaikan oleh 1 orang dosen yang ahli dibidang gizi yaitu ketua pengabdian serta dibantu oleh 3 orang mahasiswa dalam pelaksanaan teknik pengabdian. Setelah dilakukan penyuluhan, sasaran diberikan soal post-test untuk mengukur pengetahuan sasaran setelah diberikan penyuluhan.

Berdasarkan hasil pre-test dan posttest dapat diketahui bahwa nilai jawaban benar dari 10 responden yang menjawab 5 pertanyaan pun meningkat jika dibandingkan antara pre-test dan post-test, dikarenakan adanya penyampaian materi atau edukasi yang disampaikan oleh tim penyuluh setelah dilakukannya pre-test sehingga pada saat post-test dibagikan maka responden dapat mengetahui apa dan memahami materi yang telah disampaikan.

Diketahui dari soal pre-test soal pilihan ganda, sebanyak 2 orang dari 10 responden yang hanya menjawab benar. Pada soal atau pertanyaan yang ke-3 pretest, responden yang menjawab benar hanya $20 \%$ dan mengalami peningkatan pada post-test mencapai $70 \%$. Soal atau pertanyaan pre dan post-test tersebut tentang apa saja faktor yang mempengaruhi tumbuh kembang pada anak. Pada pertanyaaan soal nomor 3 yang jawaban benarnya paling sedikit jumlahnya dibandingkan soal lain, dapat dikarenakan ibu atau responden tidak pernah mendapatkan sumber informasi seperti tayangan televisi, radio, internet, koran, majalah, dan sebelumnya tidak penyuluhan mengenai faktor penyebab tumbuh kembang anak yang tidak sesuai dengan usianya.
Menurut teori, paparan informasi (pesan) yang didapatkan dari orang, media, maupun dari pendidikan seperti penyuluhan (Informan) akan mempengaruhi perubahan pada pengetahuan seseorang (receiver) (Sarwono, 1997). Oleh sebab itu, mayoritas pekerja menjawab pertanyaan dengan salah dari pertanyaan penelitian.

Berdasarkan pernyataan diatas, bahwa hampir seluruh ibu atau responden memiliki kesamaan pada saat menjawab pertanyaan yang diberikan, yaitu sama- sama kurang dalam menjawab pertanyaan pre-test pada soal nomor 3 yaitu tentang faktor yang mempengaruhi tumbuh kembang pada anak. Kondisi ini bertujuan untuk menghindari bias informasi.

Sebagian besar responden tidak mengetahui apa saja faktor yang mempengaruhi tumbuh kembang pada anak (80\%). Namun pada saat post-test terjadi peningkatan dikarenakan adanya penyuluhan sehingga responden dapat mengetahui materi tentang tumbuh kembang pada anak termasuk faktor-faktor yang mempengaruhinya. Adapun faktorfaktor yang mempengaruhi tumbuh kembang pada anak seperti faktor keturunan/genetik, faktor lingkungan, dan faktor asupan/gizi.

Hasil kegiatan pengabdian ini juga menunjukkan bahwa nilai rata- rata skor pengetahuan sebelum dilakukannya penyuluhan adalah 66 poim, dengan standar deviasi 0,82, dan nilai median 3,5. Sedangkan rata- rata skor pengetahuan sesudah dilakukannya penyuluhan adalah 80 poin, dengan standar deviasi 0,7 , dan nilai median 5. Adanya selisih antara nilai rata-rata pre-test dan post-test menunjukkan bahwa adanya peningkatan skor pengetahuan ibu sebelum dan sesudah diberikan penyuluhan.

Menurut Notoatmodjo (2003), pengetahuan merupakan kemampuan seseorang untuk mengungkapkan kembali apa yang diketahuinya dalam bentuk bukti jawaban baik lisan, atau tulisan yang merupakan stimulasi dari pertanyaan. 
Pengetahuan sesudah dilakukannya edukasi/penyuluhan terlihat lebih tinggi dibandingkan pengetahuan sebelum dilakukannya edukasi/penyuluhan, hal ini bisa terjadi dikarenakan para ibu atau responden mendapatkan penyuluhan dengan bantuan media leaflet. Perbedaan nilai rata- rata yang didapatkan cukup jauh berbeda, yakni 66 poin pada saat sebelum dilakukannya penyuluhan dan 90 poin pada saat setelah dilakukannya edukasi.

Menurut teori, peningkatan ini dikarenakan paparan informasi yang diperoleh dari media leaflet. Informasi atau pesan penyuluhan yang disampaikan dengan menggunakan media atau alat bantu pendidikan ini membantu pendidik dalam menyampaikan pesan tersebut agar terlihat menarik perhatian pada sasaran pendidikan (Notoatmodjo, 2003). Informasi yang diberikan oleh media leaflet ini karena informasi dapat langsung dibaca dan dapat dipahami, pada dasarnya isi dari media leaflet ini berupa gambar dan tulisan sehingga terlihat lebih menarik bagi sasaran pendidikan agar mempermudah sasaran pendidikan menerima pesan atau informasi. Dengan demikian fungsi dari media dapat berfungsi untuk mempertinggi daya serap dan retensi seseorang terhadap materi pembelajaran (Usman, 2002).

Pengetahuan merupakan kemampuan seseorang untuk mengungkapkan kembali apa yang diketahuinya dalam bentuk bukti jawaban baik lisan, atau tulisan yang merupakan stimulasi dari pertanyaan. Pengetahuan atau kognitif merupakan domain yang sangat penting dalam membentuk tindakan seseorang (overt behaviour). Pengukuran pengetahuan dapat dilakukan dengan wawancara atau angket yang menanyakan tentang isi materi yang ingin diukur dari subjek penelitian atau responden (Notoatmodjo, 2007).

Hasil analisis perbedaan pengetahuan sebelum dan sesudah dilakukan dengan pemberian edukasi kesehatan menunjukkan adanya perbedaan yang bermakna. Hasil ini menunjukkan, bahwa intervensi pendidikan kesehatan yang dilakukan dengan singkat akan berdampak positif dalam meningkatkan pengetahuan seseorang (Fauziah, 2012). Peningkatan tersebut diartikan sebagai hasil dari pendidikan kesehatan dengan pemberian penyuluhan dengan alat bantu berupa media leaflet. Salah satu kegiatan pendidikan kesehatan adalah suatu kegiatan pemberian informasi atau pesan berupa penyuluhan dari pemberi pesan kepada penerima pesan yang tersampaikan, akan membuat peningkatan pengetahuan dan merubah sikap seseorang tentang kesehatan dengan tujuan merubah perilaku manusia secara individu, kelompok ataupun masyarakat agar lebih baik lagi dalam menciptakan perilaku sehat (Notoatmodjo,2005).

Penyuluhan kesehatan diartikan sebagai kegiatan pendidikan kesehatan yang dilakukan dengan menyebarkan pesan ataupun informasi, sehingga masyarakat mengetahui dan mengerti untuk bisa melakukan anjuran- anjuran yang ada hubungannya dengan kesehatan (Machfoed, 2007). Adapun tujuan dari pendidikan kesehatan dengan metode penyuluhan adalah meningkatkan pengetahuan seseorang. Hal ini juga sejalan dengan hasil penelitian Fauziah (2012) yang menunjukkan bahwa ada perbedaan bermakna pada pengetahuan, sikap dan praktik sebelum dan sesudah dilakukannya edukasi. Lebih lanjut dijelaskan bahwa adanya jarak atau rentang waktu selama seminggu seseorang mendapatkan sumber informasi yang pendek pada saat pengukuran antara pengaruh pendidikan terhadap pengetahuan sikap dan praktik, akan mempengaruhi pemahaman dan kemampuan ingatan sesorang dalam menerima informasi pendidikan tersebut.

Menurut Notoatmodjo (2003) untuk mendapatkan hasil yang efektif pada peningkatan pengetahuan diperlukan alat bantu media, adapun fungsi dari media itu adalah membantu pendidik dalam menyampaikan bahan pendidikan dan untuk menarik perhatian sasaran pendidikan. 
Pemilihan dan penggunaan alat bantu media merupakan salah satu komponen yang penting dilakukan, dengan tujuan agar membantu penggunaan indera sebanyakbanyaknya. Seseorang mendapat pengetahuan melalui panca inderanya, dimana sebagian besar diperoleh melalui indera penglihatan (mata) yaitu sebesar $83 \%$ dan indera pendengar (telinga) yaitu sebesar $11 \%$, sedangkan sisanya melalui indera perasa $1 \%$, indera peraba $2 \%$, dan indera penciuman 3\% (Depkes RI, 2008, Notoatmodjo, 2003). Dengan penggunaan leaflet, informasi yang disampaikan melalui mata lebih banyak, sehingga informasi akan lebih mudah diterima oleh pekerja sebagai sasaran pendidikan.

Penyebarluasan informasi dan media pendidikan kesehatan seperti booklet, poster, leaflet dalam penelitian pendidikan kesehatan telah banyak dilakukan dan menunjukkan perubahan yang signifikan. Hal ini sejalan dengan hasil penelitian yang dilakukan oleh Setyowati (2005) di Jepara menunjukkan bahwa setelah diberikan pendidikan kesehatan dengan media leaflet, pengetahuan kelompok intervensi meningkat secara bermakna dibanding kelompok kontrol, dikarenakan penelitian di bidang pendidikan kesehatan yang dilakukan ini menunujukkan bahwa kegiatan belajar mengajar akan lebih efektif dan mudah meningkatkan pengetahuan, apabila pendidikan kesehatan ini dibantu dengan alat peraga atau alat bantu media pendidikan kesehatan.

Hal ini juga sejalan dengan hasil penelitian Koshi dan Vijayalaxmi (2009) yang menjelaskan bahwa pendidikan kesehatan dengan media booklet dan metode diskusi efektif meningkatkan pengetahuan, dikarenakan pengukuran pada pengetahuan dan sikap yang dilakukan dengan penggabungan antara pemberian metode dan pemberian alat bantu media pendidikan kesehatan, akan sangat efektif dalam peningkatan pengetahuan seseorang dalam menerima informasi atau pesan yang disampaikan oleh pendidik.
Pengetahuan juga merupakan komponen pembentuk suatu perilaku baru terutama pada orang dewasa. Dengan pengetahuan, seseorang dapat mempertimbangkan untuk bersikap dan bertindak (Benjamin S Bloom, 1956). Pengetahuan yang dimaksud adalah sebelum dilakukannya penyuluhan dan sesudah dilakukannya penyuluhan. Pengetahuan sebelum dilakukannya penyuluhan tentang tumbuh kembang anak sesuai dengan usianya adalah hal-hal yang diketahui responden mengenai apa itu tumbuh kembang, faktor yang mempengaruhi tumbuh kembang, dan dampak yang terjadi jika anak tidak tumbuh dan berkembang sesuai dengan usianya yang dinilai berdasarkan kemampuan menjawab dengan benar pertanyaan pada kuesioner sebelum dilakukan penyuluhan. Sedangkan pengetahuan sesudah dilakukannya edukasi/penyuluhan apa itu tumbuh kembang, faktor yang mempengaruhi tumbuh kembang, dan dampak yang terjadi jika anak tidak tumbuh dan berkembang sesuai dengan usianya yang dinilai berdasarkan kemampuan menjawab dengan benar pertanyaan pada kuesioner setelah dilakukannya penyuluhan.

\section{KESIMPULAN DAN SARAN}

\section{Kesimpulan}

Berdasarkan kegiatan pengabdian masyarakat yang dilakukan, maka dapat disimpulkan bahwa peserta mampu menjawab pertanyaan terkait dengan materi tumbuh kembang pada anak usia 0-5 tahun pada tahap post-test, yaitu jawaban benar sebesar $\geq 80 \%$. Peserta juga mampu memahami materi tentang tumbuh kembang anak terkait dengan pola konsumsi yang baik melalui diskusi, seperti pertanyaan yang diberikan kepada tim penyuluhan dan adanya umpan balik jawaban yang diberikan oleh tim penyuluhan. 


\section{Saran}

Berdasarkan kegiatan ini maka perlu upaya kerja sama dari petugas kesehatan dan kader untuk memotivasi ibu balita agar rutin melakukan pemantauan tumbuh kembang balita ke posyandu atau fasilitas pelayanan kesehatan terdekat

\section{UCAPAN TERIMA KASIH}

Terimakasih disampaikan kepada Sekolah Tinggi Ilmu Kesehatan Baiturrahim yang telah memberikan dukungan dana serta kepada Dinas Kesehatan Kabupaten Sarolangun yang telah memfasilitasi kegiatan ini sehingga kegiatan ini dapat terlaksana dengan baik.

\section{DAFTAR PUSTAKA}

Departemen Kesehatan RI \& Ikatan Dokter Anak Indonesia. 2010. Pedoman Pelaksanaan Stimulasi, Deteksi dan Intervensi Dini Tumbuh Kembang Anak di Tingkat Pelayanan Dasar. Jakarta: Depkes RI dan IDAI.

Depkes RI. 2004. Pengembangan Media Promosi Kesehatan. Jakarta: Depkes RI

Depkes RI. 2008. Field Book Metode dan Media Promosi Kesehatan. Jakarta: Depkes RI

Fauziah. 2012. Pengaruh Pendidikan Kesehatan Tentang Nutrisi Prakonsepsi Terhadap Tingkat Pengetahuan, Sikap, Dan Praktik Konsumsi Makanan Sehat Wanita Pranikah. Tesis. Universitas Indonesia

Machfoedz, Ircham. 2007. Pendidikan Kesehatan Bagian dari Promosi Kesehatan. Yogyakarta: Fitramaya

Murti, B.2003. Prinsip dan Metodologi Riset Epidemiologi. Ed. Kedua, Jilid
Pertama, Yogyakarta; Gajah Mada University Press.

Notoatmodjo, S. 2003. Pendidikan dan Perilaku Kesehatan. Jakarta: PT ASDI Mahasaty 2005. Promosi Kesehatan : Teori dan Aplikasi. Jakarta: PT. Rineka Cipta.

2007. Promosi Kesehatan. Jakarta: PT. Rineka Cipta. 2010. Promosi Kesehatan. Jakarta: PT. Rineka Cipta.

Nurazizah, Dhiena. 2012. Pengaruh Penyuluhan Melalui Media KIE Mengenai ASI Eksklusif dan IMD Terhadap Pengetahuan Ibu Hamil di Kelurahan Pengasinan, Kecamatan Sawangan Depok Tahun 2011. Skripsi. Universitas Indonesia

Sarwono, S, W. 2006. Psikologi Remaja. Raja Grafindo Persada : Jakarta

Setyowati, A. (2005). Pengaruh leaflet ispa / pnemonia terhadap perilaku (pengetahuan, sikap dan praktek) ibu bayi / balita dan kader tentang penatalaksanaan kasus ISPA di Kab. Jepara.

Potter, Perry. 2010. Fundamental Of Nursing: Concep, Proses and Practice. Edisi 7. Vol.3. Jakarta: EGC.

Usman, Basyiruddin. 2002. Media Pembelajaran. Jakarta: Ciputat Pers

Soetjiningsih. 2013. Tumbuh Kembang Anak. Jakarta: EGC 